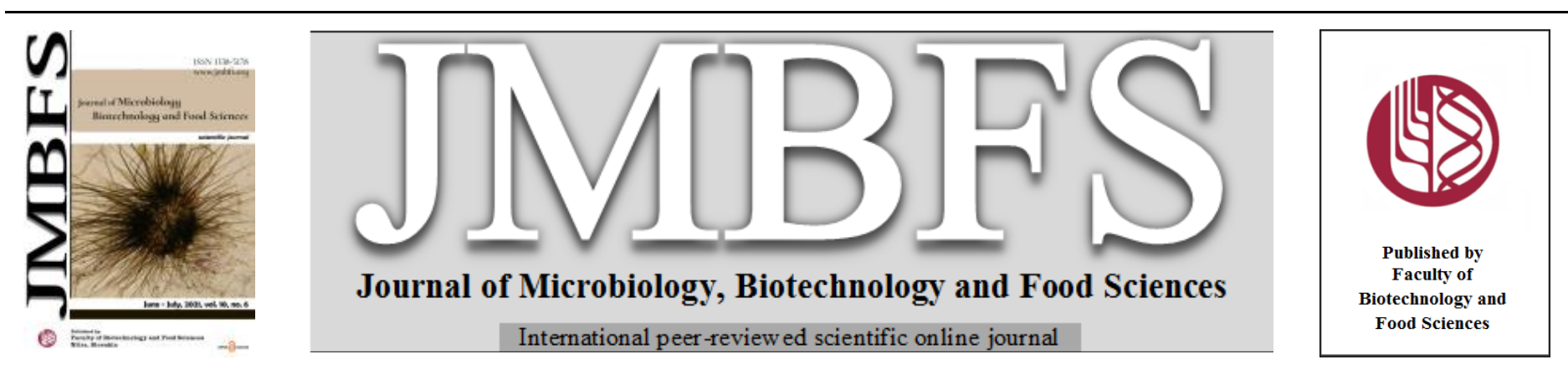

\title{
EFFICACY OF GREEN TEA EXTRACT (GTE) AGAINST HIGHLY PATHOGENIC H5N1 AVIAN INFLUENZA VIRUS; IN VIVO AND IN VITRO STUDY
}

\author{
Marwa A Abdelmagid ${ }^{3}$, Gehan G Ahmed ${ }^{2}$, Abdullah A Selim ${ }^{3}$, Walid H Kilany ${ }^{3}$, Sherein S Abdelgayed ${ }^{*}$, Hala M.F.El-Miniawy $^{l}$
}

\section{Address(es):}

${ }^{1}$ Department of pathology, faculty of veterinary medicine, Cairo University, 12211, Giza, Egypt.

${ }^{2}$ Department of pathology, animal health research institute, 12211, Giza, Egypt.

${ }^{3}$ Reference Lab for Veterinary Quality Control on Poultry Production, animal health research institute, 12211, Giza, Egypt.

*Corresponding author: sherein.abdelgayed@vet.cu.edu.eg

https://doi.org/10.15414/jmbfs.2735

\section{ARTICLE INFO}

Received 6. 3. 2020

Revised 15. 12. 2020

Accepted 17. 12. 2020

Published 1. 6. 2021

Regular article open $\mathcal{C}_{\text {ACCESS }}$

\begin{abstract}
Highly pathogenic avian influenza virus (HPAIV) H5N1 is an endemic disease in Egypt and severe outbreaks have been reported even in vaccinated flocks. Several H5 vaccines have failed to protect birds against Egyptian H5N1 virus. In this study, the antiviral effect of green tea extract (GTE) in combination with inactivated H5N1 vaccine was evaluated. GTE found to be safe at high concentration on Vero cells and decrease the CPE on infected cells. In vivo, specific pathogen free chickens were allocated into four groups, 15 birds each. Negative control group, positive control group, vaccinated group, vaccinated group supplied by GTE in drinking water $(5 \mathrm{gm} / \mathrm{L})$. Blood samples were collected weekly and tested using (HI) test. Lung tissue specimens collected for histopathology and immunohistochemistry. Interestingly, vaccinated non-treated birds exhibited severe post vaccinal reaction and deaths. GTE in combination with inactivated vaccine increased HI titer one-week post vaccination, and no deaths were recorded in this group. Moreover, treated chickens did not excrete virus in swab samples and minimal antigen and pathological changes were reported in its lungs. The addition of GTE prevent the shedding of the virus and achieve complete protection against HPAI.
\end{abstract}

Keywords: chicken, Green tea extract (GTE), inactivated H5N1 vaccine, antiviral, immunohistochemistry, H5N1

\section{INTRODUCTION}

Since 1996/1997, HPAIV H5N1 virus devastated the poultry in over 60 countries and eventually became endemic in few countries in Asia and Africa (Alexander, 2007). Poultry in Egypt has been endemic with the virus since 2006 remarking the longest period of endemic status outside Asia. The virus has caused significant economic losses in poultry industry. It is worth mentioning that Egypt is the country with the highest number of human infections with H5N1 worldwide (Abdelwhab et al., 2016; Bakeer et al., 2019). Culling of infected poultry overwhelms the vulnerable economy of the country and therefore blanket vaccination strategy has been implemented since 2006 to reduce the losses. To date, several inactivated $\mathrm{H} 5$ vaccines are used in commercial poultry with highly variable regimes and providers (Abdelwhab et al., 2016). Vaccination decreased morbidity, mortality, virus excretion, bird-to-bird transmission and reduction in egg production (Kandeil et al., 2017). Nevertheless, infection of vaccinated birds has been frequently reported due to the emergence of antigenic drift variants, immune suppression, or improper handling and production of the vaccine (Abdelwhab et al., 2016).The use of herbals as alternative or supportive tools for the control of AIV have been comprehensively reviewed (Wang et al., 2006; Abdelwhab \& Hafez, 2012; Afsheen et al., 2019). Green tea (Camellia sinensis) and its by-product possess multifunctional activities against AIV either through antioxidant properties of its component (Lis-Balchin et al., 2000; Peluso \& Serafini, 2017) that maintain the immune cells and protect them from the adverse environment and oxidative stress (De la Fuente \& Victor, 2000; Khan et al., 2016) or through direct effect on the virus by inhibit its adsorption to cells, and thus block its infectivity (Mukhtar \& Ahmad, 2000) inhibition of the virus growth (Imanishi et al., 2002), and by inhibitory effect on virus release step through inhibition of neuraminidase (Song et al., 2005). Use of botanicals in the prevention and treatment are gaining importance day by day (Khater $\boldsymbol{e t}$ al., 2020). Among these, green tea is the one. The application of lyophilized green tea extracts (GTE) in feed or drinking water reduced the replication and excretion in H9N2 experimentally infected chickens (Lee $\boldsymbol{e t}$ al., 2012). Moreover, GTE was effective as amantadine in protection of chicken embryos against an H7N3 AIV (Shaukat et al., 2011) or cell culture after infection with H5N1 virus (Deryabin et al., 2008). Interestingly, GTE was found to enhance the immune response of mice to influenza vaccines (Won et al., 2017; Zaman et al., 2019).
In this study, the synergistic effect of GTE in combination with inactivated H5N1 vaccine on the protection of chicken against HPAIV H5N1 was investigated.

\section{MATERIALS AND METHODS}

All studies carried out in reference laboratory for veterinary quality control on poultry production according to vet.cu.IACUC guidelines for research ethics in animals.

\section{Green tea extract (GTE)}

Using of Methanolic extract of green tea in drinking water(5gm/liter) which obtained according to "Harbone, 1994" by soxhlet of $25 \mathrm{~g}$ dried leaves (from Egyptian local market) in 250ml 95\% methanol for 6 hours.

\section{Virus and vaccine}

Highly pathogenic avian influenza A/chicken/Egypt/1575S/2015(H5N1) virus was kindly provided by the RLQP (Reference laboratory for quality control on poultry production), Egypt. The virus titer was determined using the method of Reed and Munch "Reed \& Meunch, 1938". Challenge was done on the $28^{\text {th }}$ day old using $10^{6} \mathrm{EID}_{50} / 100 \mu \mathrm{l} / \mathrm{bird}$ through intranasal route. Commercial inactivated H5N1 vaccine (Re1) was used at day 7 via subcutaneous injection of $0.3 \mathrm{ml}$ per chick.

\section{Evaluation of cytotoxicity and antiviral activity of GTE in-vitro}

Vero cell line (kidney epithelial cells extracted from an African green monkey) was supplied by VacSera, Egypt. Confluent monolayer cells seeded in 24-well plates for $24 \mathrm{~h}$ to in Eagle's maintenance medium, supplemented with $2 \%$ fetal bovine serum (BioResearch, Lonza, USA) was used to study the cytotoxicity of GTE. Different concentrations of the extract $(20 \%, 40 \%, 60 \%, 80 \%$ and $100 \%)$ were added to the cells and incubated for 3 days at $37^{\circ} \mathrm{C}$. Thereafter, the cells were stained with crystal violet stain (1gm crystal violet in $20 \%$ ethanol)/45 minutes. The $1^{\text {st }}$ column of confluent sheet of Vero cell line 24 plate was infected 
with 300ul virus and incubated $1 \mathrm{~h}$ for viral adsorption followed by $300 \mathrm{ul}$ of selected GTE concentration $(5 \mathrm{gm} / \mathrm{liter})$, the $2^{\text {nd }}$ column was inoculated with 300ul GTE $(5 \mathrm{gm} / \mathrm{liter})$ and incubated for $1 \mathrm{~h}$ followed by virus infection, $3^{\text {rd }}$ column was inoculated with mixture of the virus and the extract after $1 \mathrm{~h}$ contact time, other columns of the plate used for control; examined plate was incubated for 3 days in $\mathrm{CO} 2$ incubator at $37{ }^{\circ} \mathrm{C}$ and $5 \% \mathrm{CO} 2$ then stained with crystal violet stain $(0.1 \%$ crystal violet in $20 \%$ ethanol) for microscopical evaluation of viral cytopathic effect (rounding, elongation \& disintegration) using inverted microscope.

\section{Evaluation of antiviral activity of GTE in-vivo}

Sixty, one-day old specific pathogen free (SPF) chicks were hatched from SPF fertile chicken eggs obtained from Nile SPF Company (Koom Oshiem, Fayoum, Egypt) and reared in HEPA-filtered negative pressure isolators. Birds were allocated into 4 groups, 15 birds each: negative control (group A), positive control (group B), vaccinated group (group C) and treated vaccinated group (group D). Groups B, C, and D were challenged on the $28^{\text {th }}$ day old using $10^{6}$ $\mathrm{EID}_{50} / 100 \mu 1$ through the intranasal route.

\section{Pathological and immunohistochemical examination}

Clinical signs were recorded daily post challenge (PC). Two birds from each group were euthanized at 1, 3, 7 and 10 days (PC). Gross lesions were recorded in those euthanized birds as well as freshly dead chicken. Tissue specimens from lung were collected and fixed in $10 \%$ neutral buffered formalin and processed by paraffin embedding technique for histopathological examination (Li et al., 2020). For immunohistochemistry (IHC) staining, paraffinized tissue sections $(6 \mu \mathrm{m}$ thick) were stained by immunoperoxidase technique using primary antibody polyclonal H5 primary antibody (GD Diagnostics, GD- Animal Health, the Netherlands) and goat anti-chicken horseradish peroxidase HRP (KPL, USA) conjugate antibodies $1: 100$, then the slides were covered with a freshly prepared chromogen/substrate reagent solution such as DAB/H2O2 (Sigma Aldrich, Germany) for 3 minutes. After staining, the sections were counterstained with hematoxylin (Survana et al. 2013).

\section{Morphometric analysis}

Morphometric analysis was carried out for the immunohistochemical stained lung sections using optical microscope. Images were captured by a digital camera (Leica, DM2500 M). A freeware version of Image-J (1.45s) downloaded from the $\mathrm{NIH}$ website was used for image analysis preceded by calibration of the scale was changed to micrometers using set scale analysis. Quantification of area percentages of positive immunohistochemical reactions was carried out in 60 captured microscopic images at 600.x magnification fields "Schneider $\boldsymbol{e t}$ al. (2012)".

\section{Hemagglutination inhibition (HI)}

Blood samples were collected from vaccinated chicks (groups C \& D) at 1, 2, 3 and 5 weeks of age to evaluate antibody titer using HI test according to the standard protocol "OIE, 2015".

\section{Real time reverse-transcription polymerase chain reaction (RT-qPCR)}

Tracheal swabs obtained from challenged birds (groups B, C \& D) at 3, 7 and 10 days (PC) were examined by RT-qPCR to detect viral shedding. Automated extraction of viral RNA using a MagNA Pure LC Total Nucleic Acid Extraction Kit (Roche, Mannheim, Germany). Detection of Matrix gene, Primers \& probe prepared according to (Spackman, 2002) using StratageneMX3005P Real time PCR machine (Stratagene, USA).

\section{Statistical analysis}

Data were analyzed by IBM SPSS Statistics Base 20.0 statistical software for Windows ${ }^{\circledR}$. HI titer data were analyzed using independent sample T-test. Oneway analysis of variance (ANOVA) using least significant difference (LSD) for mean comparisons of IHC image analysis. The results were considered significantly different $(\mathrm{P}<0.05)$ between means having the same capital and small letter. The results are presented as mean \pm standard deviation (SD) or standard error (SE).

\section{RESULTS AND DISCUSSION}

\section{Evaluation of GTE cytotoxicity on vero cell line}

All examined concentrations of GTE $(20 \%, 40 \%, 60 \%, 80 \% \& 100 \%)$ didn't revealed cytopathic changes on vero cell line within 3 days of incubation and the cells remain intact.

\section{Evaluation of antiviral efficacy of GTE on vero cell line}

The microscopical examination of stained vero cells treated with the selected dilution of GTE $(5 \mathrm{gm} / \mathrm{litre})$ showed desirable antiviral effect against AIV (H5N1); the inoculation of GTE $1 \mathrm{~h}$ after viral infection resulted in complete disappearance of viral cytopathic effect on vero cells as well as when the cells were inoculated with mixture of GTE and the virus, while the infection of vero cell line with the virus $1 \mathrm{~h}$ post inoculation of GTE resulted in decreasing the viral cytopathic effect on vero cells ranging from $(80 \%-100 \%)$ as showing in [Table 1]. In this respect, (Imanishi $\boldsymbol{e t}$ al. 2002) demonstrated inhibitory effect of GTE (1:20 dilution) on the growth of influenza virus (H1N1) in MDCK by preventing acid catalysed fusion reaction. "Song et al. (2005)" suggested that the antiviral effect of GTE (catechin) is exerted on the initially infecting viruses and also on the newly propagated viruses as well as it has additional inhibitory effect on release step through inhibition of neuraminidase.

Table 1 Viral cytopathic effect on treated vero cells with GTE.

\begin{tabular}{lcccccc}
\hline$*$ I.P/h & \multicolumn{7}{c}{ Cytopathic changes (\%) } \\
\cline { 2 - 7 } & $\mathrm{A}$ & $\mathrm{B}$ & $\mathrm{C}$ & $\mathrm{D}$ & $\mathrm{E}$ & $\mathrm{F}$ \\
24 & $0 \%$ & $0 \%$ & $0 \%$ & $0 \%$ & $70 \%$ & 0 \\
48 & $0 \%$ & $0 \%$ & $0 \%$ & $0 \%$ & $30 \%$ & 0 \\
72 & $0 \%$ & $20 \%$ & $0 \%$ & $0 \%$ & $\mathrm{ND}$ & 0 \\
$\begin{array}{l}\text { Non affected } \\
\text { cells }\end{array}$ & $100 \%$ & $80 \%$ & $100 \%$ & $100 \%$ & $0 \%$ & $100 \%$ \\
\hline
\end{tabular}

*Incubation period/hours, ND: not done, A: treatment of cells with GTE $1 \mathrm{hr}$ post infection, B: infection of the cells $1 \mathrm{hr}$ post GTE treatment, C: inoculation of mixture (GTE+virus), D: inoculation of GTE only, E: inoculation of virus only, F: negative control

\section{In-vivo study}

\section{Clinical signs}

The positive control group (B) showed mild clinical signs $24 \mathrm{hs}$ post challenge including ruffled feather and respiratory manifestations as well as marked depression. Within $36 \mathrm{hs}$ post challenge, marked clinical signs proceeded including severe respiratory manifestation, cyanosis of comb with sudden death of all chickens of positive control group. These results equivalent to other previous studies mentioned mild clinical signs with sudden deaths within $48 \mathrm{hs}$ from infection in experimented SPF chicken (Fatma, 2016). On the other hand, the vaccinated birds showed normal status except mild depression and one bird died on the fourth day post challenge showing typical influenza signs including, congestion of comb and haemorrhage of shank as well as defeathering. In group (D), the birds showed normal healthy appearance along the experimental period without any abnormalities or deaths.

\section{Histopathology}

The pulmonary lesions in group (B) characterized by severe vascular and exudative reaction. It begins $24 \mathrm{hs}$ post challenge as severe dilatation and congestion of pulmonary blood vessel [Fig. 1]; severe bronchopneumonia manifested by large extended inflammatory exudate in the bronchi and parabronchi [Fig. 2]. The interstitial septa become widened by severe inflammatory edema [Fig. 3] with vasculitis of blood vessels and intra vascular coagulation. The severe exudative inflammatory reaction was attributed to the endothelial cell tropism of the virus with massive viral replication resulted in tissue destruction (Seidavi et al. 2014). It's clear that the lung is the primary target for influenza virus and also the choreographers for cytokines amplification during infection that's responsible for the pathological alterations and pathogenesis of the disease in severe influenza infection (Teijaro et al. 2011). In group $(\mathrm{C})$, the pulmonary tissue revealed post vaccinal reaction beginning $24 \mathrm{hs}$ post challenge manifested by severe vascular congestion and vasculitis with thrombus formation. The lung tissue exhibited mild bronchopneumonia with marked smooth muscle hypertrophy in tertiary bronchi [Fig. 4]. The lung of living chickens at the end of experiment (14ds post challenge) showed severe congestion of pulmonary blood vessels and haemorrhages in the lung tissue [Fig. 5].

Group (D): the lung of this vaccinated treated group exhibited marked improvement of pulmonary lesions [Fig. 6]. The histopathological improvement detected in the lung may be attributed to the green tea as antiviral agent protecting against cytokines storm in severe influenza infection as illustrated by (Liu et al. 2016).

\section{Immunohistochemistry}

AI Viral antigen was intensively detected in the lung tissue of positive control group (B) represented by dense brown granules widely distributed within the lung tissue [Fig. 7] and mainly recorded in the tertiary bronchi and intermingled with inflammatory exudates and also was densely detected in the endothelial 
lining of pulmonary blood vessel.In group (C), the antigen was widely distributed and densely expressed within the lung tissue [Fig. 8] and in the wall of blood vessels, while in group (D) was mildly expressed in the lung tissue [Fig. 9].


Figure 1 Lung of chicken from group (B) showing severe congestion and dilatation of pulmonary blood vessels (arrow) with mild inflammatory edema in the C.T septa (arrow) (H\&E X 100), Figure 2: Lung of chicken from group (B) showing extended inflammatory exudates within tertiary bronchi (arrow) (H\&E X 200), Figure 3: Lung of chicken from group (B) showing widening of C.T septa with inflammatory edema. Note: the extensive lymphocytic infiltration in the lung parenchyma (arrow) (H\&E X 100), Figure 4: Lung of chicken from group (C) showing severe marked smooth muscle hypertrophy in tertiary bronchi (arrow) (H\&E X400), Figure 5: Lung of chicken from group (D) showing severe congestion of interstitial blood vessels with focal hemorrhages in lung tissue (arrow) (H\&E X100), Figure 6: Lung of chicken from group (D) showing few lymphocytic cells infiltration in pulmonary blood vessels (H\&E X200), Figure 7: Immunohistochemical demonstration of wide spreading AI virus antigen in the lung tissue of group (B). (Immunoperoxidase complex with counter stain Mayer's haematoxylin X600). Figure 8: Immunohistochemical demonstration of marked AI virus antigen distribution in lung tissue and in the wall of blood vessel of group (C) (Immunoperoxidase complex with counter stain Mayer's haematoxylin X600). Figure 9: Immunohistochemical demonstration of scattered AI virus antigen in the vicinity of the lung tissue of group (D) (Immunoperoxidase complex with counter stain Mayer's haematoxylin X600).

\section{Morphometric analysis}

The morphometric analysis of the viral antigen expression revealed that the smallest area of distribution \% was in group (D) while group (C) was quite similar as group (B)

\section{Heamagglutination inhibition test}

The results revealed significant difference between the treated vaccinated group rather than non-treated vaccinated group (vaccine only) at one-week post vaccination as the mean titre of treated group was 7.2 and 6.0 in non-treated group [table 2]. This result indicates an early immunostimulatory effect of GTE. Our finding was quite similar with that of (Seidavi et al., 2014; Kitazato et al., 2007) who didn't show a clear favourable influence in the broilers humeral immune response supplemented with green tea powder.
Table 2 Weekly HI titers means in vaccinated groups $(\log 2 \pm \mathrm{SD})$.

\begin{tabular}{lcccc}
\hline \multirow{2}{*}{ Time } & \multicolumn{2}{c}{$\begin{array}{c}\text { Group }(\mathrm{H}) \mathrm{GTE}+\mathrm{RE} 1 \\
\text { vaccine }\end{array}$} & Group $(\mathrm{G}) \mathrm{Re}-1$ vaccine \\
\cline { 2 - 5 } & Mean $\pm \mathrm{SD}$ & Post $\%$ & Mean $\pm \mathrm{SD}$ & Post $\%$ \\
$\begin{array}{l}\text { 1 week post } \\
\text { vaccination }\end{array}$ & $7.2 \pm 0.7^{\mathrm{a}}$ & $100 \%$ & $6.0 \pm 1.0^{\mathrm{b}}$ & 100 \\
2 week post & $10 \pm 0.0^{\mathrm{a}}$ & $100 \%$ & $9.9 \pm 0.5^{\mathrm{a}}$ & 100 \\
$\begin{array}{l}\text { vaccination } \\
\text { vaccination }\end{array}$ & $10 \pm 0.0^{\mathrm{a}}$ & $100 \%$ & $9.9 \pm 0.3^{\mathrm{a}}$ & 100 \\
1 week post challenge & $9.7 \pm 0.3^{\mathrm{a}}$ & $100 \%$ & $9.9 \pm 0.3^{\mathrm{a}}$ & 100 \\
\hline
\end{tabular}

There is a significant difference $(\mathrm{P}<0.05)$ between means having different litters in the same row 


\section{Estimation of viral shedding using Quantitative RT-PCR}

The virus detected in all swabs from positive control group (B) while in group (C), the percentage of shedding was $46 \%$ and in group (D) no viral shedding was detected, [table 3]. This result may indicate that GTE interfere with the release of the virus as mentioned previously by (Song et al. 2005). Although AI vaccines reduce the replication of HPAI viruses in the respiratory and gastrointestinal tract, virus shedding after vaccination was observed (Capua et al. 2003; Hafez et al. 2010).

$\underline{\text { Table } 3 \text { AI virus quantification mean in shedder birds }}$

\begin{tabular}{lccccc}
\hline Group & $\begin{array}{c}\text { No. of } \\
\text { shedder }\end{array}$ & $\begin{array}{c}\text { Percent } \\
\text { of } \\
\text { shedding }\end{array}$ & $\begin{array}{c}\text { Mean of } \\
\text { PCR copies } \\
(\log 10 / \mathrm{ml})\end{array}$ & $\begin{array}{c}\text { No. of } \\
\text { deaths }\end{array}$ & $\begin{array}{c}\text { Clinical } \\
\text { protection } \\
\%\end{array}$ \\
\hline B & $15 / 15$ & $100 \%$ & 5.7 & $15 / 15$ & 0 \\
C & $7 / 15$ & $46 \%$ & 5.7 & $1 / 15$ & 93 \\
D & $0 / 15$ & $0 \%$ & 0 & $0 / 15$ & 100 \\
\hline
\end{tabular}

\section{CONCLUSION}

From our study, we could conclude that the addition of GTE in the drinking water of vaccinated chickens and infected with (H5N1) prevent the shedding of the virus and achieve complete protection against HPAI

Acknowledgments: Reference laboratory for quality control on poultry production (RLQP) is appreciated for financial and technical support for this study. The authors acknowledge all colleagues in the RLQP, ministry of agriculture, Egypt for their valuable support during the study.

\section{REFERENCES}

Abdelwhab E., \& Hafez H, (2012). Insight into alternative approaches for control of avian influenza in poultry, with emphasis on highly pathogenic H5N1. Viruses, 4(11), 3179-3208. http://dx.doi.org/10.3390/v4113179

Abdelwhab EM, Hassan MK, Abdel-Moneim AS, Naguib MM, Mostafa A, Hussein IT, et al., (2016). Introduction and enzootic of A/H5N1 in Egypt: Virus evolution, pathogenicity and vaccine efficacy ten years on. Infection, Genetics and Evolution, 40, 80-90.

Afsheen, N., Rehman, K.U., Jahan, N., Khan, K.M. \& Zia, M.A. (2019) Optimization of cardioprotective potential of various concentrations of medicinal plants by using response surface methodology. Pakistan Veterinary Journal, 39, 13-18. http://dx.doi.org/10.29261/pakvetj/2018.111

Alexander DJ. (2007). An overview of the epidemiology of avian influenza. Vaccine, 25(30),

5644. http://dx.doi.org/10.1016/j.meegid.2016.02.023

Bakeer, A.M., Khattab, M.S., Aly, M.M., Arafa, A.S., Amer, F., Hafez, H.M. \& Afify, M.M.H. (2019). Estimation of pathological and molecular findings in vaccinated and non-vaccinated chickens challenged with highly pathogenic avian influenza H5N1 virus. Pakistan Veterinary Journal, 39, 31-36. http://dx.doi.org/10.29261/pakvetj/2018.112

Capua I, Terregino C, Cattoli G., Mutinelli F., \& Rodriguez JF. (2003) Development of a DIVA (Differentiating Infected from Vaccinated Animals) strategy using a vaccine containing a heterologous neuraminidase for the control of avian influenza. Avian Pathology, 32(1), 4755. http://dx.doi.org/10.1080/0307945021000070714

De la Fuente M., \& Victor VM. (2000). Anti-oxidants as modulators of immune function. Immunology and cell biology, 78(1), 49-54

Deryabin PG, Lvov DK, Botikov, AG, Ivanov V, Kalinovsky T, Niedzwiecki A. \& Rath M. (2008). Effects of a nutrient mixture on infectious properties of the highly pathogenic strain of avian influenza virus A/H5N1. Biofactors, 33(2), 8597. http://dx.doi.org/10.1002/biof.5520330201

Fatma AA. (2016). Experimental studies on pathological and immunological aspects on avian influenza virus in SPF chickens. Ph. D. thesis, faculty of veterinary medicine, Cairo Univ., Egypt.

Hafez MH, Arafa A, Abdelwhab EM, Selim A, Khoulosy SG, Hassan MK., \& Aly MM. (2010). Avian influenza H5N1 virus infections in vaccinated commercial and backyard poultry in Egypt. Poultry science, 89(8), 1609. 1613. http://dx.doi.org/10.3382/ps.2010-00708

Harbone NV. (1994). Phytochemical method. A guide to modern techniques of plant analysis. 2nd ed., Chapman and Hall London.

Imanishi N, Tuji Y, Katada Y, Maruhashi M, Konosu S, Mantani, N, et al. (2002). Additional inhibitory effect of tea extract on the growth of influenza A and B viruses in MDCK cells. Microbiology and immunology, 46(7), 491-494. http://dx.doi.org/10.1111/j.1348-0421.2002.tb02724.x

Kandeil A, Mostafa A, El-Shesheny R, El-Taweel AN, Gomaa M, Galal, H, et al. (2017). Avian influenza H5N1 vaccination efficacy in Egyptian backyard poultry. Vaccine, 35(45), 6195-6201.

Khan A, Ali NH, Santercole V, Paglietti B, Rubino S, Kazmi SU., \& Farooqui A (2016). Camellia sinensis mediated enhancement of humoral immunity to particulate and non-particulate antigens. Phytotherapy research,30(1), 41 48. http://dx.doi.org/10.1016/i.vaccine.2017.09.040

Khater, H.F., Ziam, H., Abbas, A., Abbas, R.Z., Raza, M.A., Hussain, K. Younis, E.Z., Radwan, I.T. \& Selim, A. (2020). Avian coccidiosis: Recent advances in alternative control strategies and vaccine development. Agrobiological Records 1, 11-25.

Kitazato K, Wang Y., \& Kobayashi N. (2007). Viral infectious disease and natural products with antiviral activity. Drug Discover Therapy, 1(1), 14-22.

Lee, HJ, Lee YN, Youn HN, Lee DH, Kwak JH, Seong BL, et al. (2012). Antiinfluenza virus activity of green tea by-products in vitro and efficacy against influenza virus infection in chickens. Poultry science,91(1), 66-73. http://dx.doi.org/10.3382/ps.2011-01645

Lis-Balchin M, Hart SL., \& Deans, SG. (2000). Pharmacological and antimicrobial studies on different tea-tree oils (Melaleuca alternifolia, Leptospermum scoparium or Manuka and Kunzea ericoides or Kanuka), originating in Australia and New Zealand. Phytotherapy Research: An International Journal Devoted to Pharmacological and Toxicological Evaluation of Natural Product Derivatives, 14(8), 623-629.

Liu Q, Zhou YH., \& Yang ZQ. (2016). The cytokine storm of severe influenza and development of immunomodulatory therapy. Cellular \& molecular immunology, 13(1), 3. http://dx.doi.org/10.1038/cmi.2015.74

Mukhtar H., \& Ahmad N. (2000). Tea polyphenols: prevention of cancer and optimizing health. The American journal of clinical nutrition, 71(6), 1698S 1702S. http://dx.doi.org/10.1093/ajen/71.6.1698S

OIE. (2015). Manual of diagnostic tests and vaccines for terrestrial animals: Avian influenza. Available online at: Https://www.Oie.Int/fileadmin/home/eng/health standards/tahm/2.03.04 ai.Pdf.

Peluso, I., \& Serafini, M. (2017). Antioxidants from black and green tea: from dietary modulation of oxidative stress to pharmacological mechanisms. British journal of pharmacology, 174(11), 1195 1208. http://dx.doi.org/10.1111/bph.13649

Reed, L. J., \& Muench, H. (1938). A simple method of estimating fifty per cent endpoints. American journal of epidemiology, 27(3), 493-497.

Schneider, C. A., Rasband, W. S., \& Eliceiri, K. W. (2012). NIH Image to ImageJ: 25 years of image analysis. Nature methods, 9(7), 671. http://dx.doi.org/10.1038/nmeth.2089

Seidavi, A., Asadpour, L., Dadashbeiki, M., \& Payan-Carreira, R. (2014). Effects of dietary fish oil and green tea powder supplementation on broiler chickens immunity. Acta Scientiae Veterinariae, 42(1), 1-13.

Shaukat, T. M., Ashraf, M., Omer, M. O., Rasheed, M. A., Muhammad, K. Shaukat, T. M., \& Shahzad, M. K. (2011). Comparative efficacy of various antiviral agents against avian influenza virus (Type H7N3/Pakistan/2003). Pakistan Journal of Zoology, 43(5).

Song, J. M., Lee, K. H., \& Seong, B. L. (2005). Antiviral effect of catechins in green tea on influenza virus. Antiviral research,68(2), 66 74. http://dx.doi.org/10.1016/j.antiviral.2005.06.01

Spackman, E., Senne, D. A., Myers, T. J., Bulaga, L. L., Garber, L. P., Perdue, M. L., \& Suarez, D. L. (2002). Development of a real-time reverse transcriptase PCR assay for type A influenza virus and the avian $\mathrm{H} 5$ and $\mathrm{H} 7$ hemagglutinin subtypes. Journal of clinical microbiology, 40(9), 3256 3260. http://dx.doi.org/10.1007/s12033-009-9211-7

Survana, K.S.L., \& Bancroft, Ch. (2013).Theory and practice of histological techniques. 7th ed., Churchill, Livingston: New York.

Teijaro, J. R., Walsh, K. B., Cahalan, S., Fremgen, D. M., Roberts, E., Scott, F., \& Rosen, H. (2011). Endothelial cells are central orchestrators of cytokine amplification during influenza virus infection. Cell, 146(6), 980-991. https://doi.org/10.1016/j.cell.2011.08.015

Wang, X., Jia, W., Zhao, A., \& Wang, X. (2006). Anti-influenza agents from plants and traditional Chinese medicine. Phytotherapy Research: An International Journal Devoted to Pharmacological and Toxicological Evaluation of Natural Product Derivatives, 20(5), 335-341. http://dx.doi.org/10.1002/ptr.1892

Won, Y. S., Kumazoe, M., Takamatsu, K., Shinoda, Y., Sonoda, S., Okada, K., \& Tachibana, H. (2017). Green tea cultivar 'Benifuuki'potentiates split vaccineinduced immunoglobulin A production. Journal of natural medicines, 71(1), 68 75. http://dx.doi.org/10.1007/s11418-016-1028-7

Zaman, A., Haleem, A., Rahman, S.U. \& Ullah, N. (2019). Seroprevalence and risk factors association of avian influenza in desi chicken (Gallus domesticus) in Khyber Pakhtunkhwa, Pakistan. Pakistan Veterinary Journal, 39, 297-300. http://dx.doi.org/10.29261/pakvetj/2019.012 